\title{
Salvaging on the Coast of Erebus Bay, King William Island: An Analysis of Inuit Interaction with Material from the Franklin Expedition
}

\author{
Dana Thacher ${ }^{1}$
}

(Received 9 March 2018; accepted in revised form 12 July 2018)

\begin{abstract}
Over the course of the 19th century, many European explorers sailed in search of a Northwest Passage through the Canadian Arctic. These journeys brought them into territory occupied by Inuit, who both traded with the explorers for various goods and interacted with the material that they left behind. This study examines the remains of two ship's boats from three sites on King William Island ( $\mathrm{NgLj}-2, \mathrm{NgLj}-3$, and $\mathrm{NgLj}-8$ ) that were abandoned by members of the Franklin expedition and subsequently found and altered by an Inuit sub-group called the Netsilik to reveal the motivational factors behind their actions. It demonstrates that Inuit used these boats in a manner that reflects (1) their environment, (2) what the material afforded, (3) their past experiences with Europeans and European material, and (4) their intended uses of the material. These alterations ascribed new meaning to the material and redefine the remains of the boats in Erebus Bay as simultaneously Netsilik and European material.
\end{abstract}

Key words: Franklin expedition; archaeology; Netsilik Inuit; King William Island; salvage; Erebus Bay; boat places

RÉSUMÉ. Au cours du XIX siècle, de nombreux explorateurs européens ont mis le cap sur l'Arctique canadien à la recherche du passage du Nord-Ouest. Ces expéditions les ont emmenés vers des territoires occupés par les Inuits. Ceux-ci ont troqué diverses marchandises avec les explorateurs et utilisé le matériel que ces derniers ont laissé sur leur passage. Cette étude examine les restes des embarcations de deux navires en provenance de trois sites de l'île King William (NgLj-2, NgLj-3 et NgLj-8) abandonnées par des membres de l'expédition Franklin. Ces embarcations avaient été trouvées et modifiées par un sous-groupe inuit du nom de Netsilik. L'examen des restes vise à révéler les facteurs les ayant motivés à agir ainsi. Elle démontre que les Inuits se sont servi de ces embarcations de manières qui tiennent compte 1) de leur environnement; 2) de ce que le matériel leur permettait de faire; 3) de leurs expériences antérieures avec les Européens et le matériel européen; et 4) de leurs usages prévus du matériel. Ces modifications ont conféré un nouveau sens au matériel et permettent de redéfinir les restes des embarcations de la baie Erebus comme étant à la fois du matériel netsilik et européen.

Mots clés : expédition Franklin; archéologie; Inuit Netsilik; île King William; récupérer; baie Erebus; lieux d'embarcations

Traduit pour la revue Arctic par Nicole Giguère

\section{INTRODUCTION}

During the 19th century, many European explorers were sent to the Arctic in search of a Northwest Passage (Cyriax, 1939; Hickey, 1984:17; Berton, 1988), and over the course of these voyages, storehouses, supply cairns, and, in some cases, ships were left scattered throughout the region. Inuit later encountered these features and salvaged what material was useful to them. In the process, they altered European materials to suit their own needs, and these alterations often ascribed new meaning to the material that differed from the intent of European manufacturers. By closely observing such alterations, we can examine the role that Inuit played in constructing what we see in the archaeological record today and describe how we categorize and portray material that began in one context but was incorporated into another.
The ill-fated Franklin expedition was one such exploratory voyage that resulted in European material being abandoned in the Central Arctic. The expedition, led by Sir John Franklin, departed England in 1845 with two ships, HMS Erebus and HMS Terror (Sutherland, 1985:v; Beattie and Geiger, 1988:9). On this expedition, 129 men sailed into the Canadian Arctic, but unfortunately, none of them would return to England. Both ships became locked in ice near King William Island (KWI) (Fig. 1) in 1846, and by April 1848, the party had been reduced from 126 (three crew members passed away at Beechey Island) to 105, and the ships were deserted (Cyriax, 1939:94; Sutherland, 1985:v). Dragging boats on sledges, the survivors made their way south along the west coast of KWI then eastward towards Back River, and all lost their lives in this final trek. Two archaeological sites that are the focus of this

\footnotetext{
${ }^{1}$ Department of Anthropology, McMaster University, Chester New Hall Rm. 524, 1280 Main St. W. Hamilton, Ontario L8S 4L9, Canada; danathacher@gmail.com

(C) The Arctic Institute of North America
} 


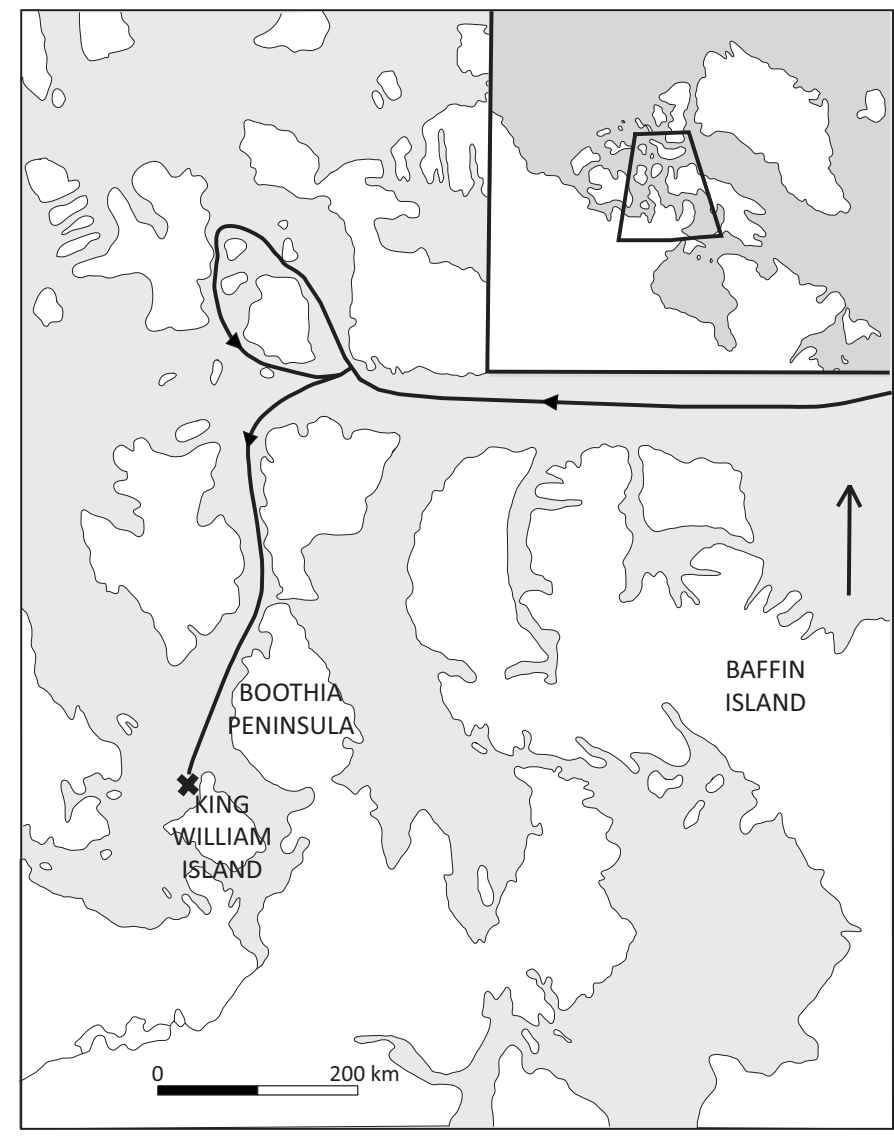

FIG. 1. Franklin's route through the Canadian Arctic (redrawn after Mays et al., 2015: Fig. 1).

study, $\mathrm{NgLj}-2$ and $\mathrm{NgLj}-3$, mark the locations of two boats that are believed to have been abandoned in Erebus Bay on KWI by members of the Franklin expedition and later found by Netsilik Inuit (Stenton and Park, 2017). This study also includes data from a third site at Erebus Bay, $\mathrm{NgLj}-8$, which contained expedition material thought to have been acquired by Inuit from $\mathrm{NgLj}-2$ and $\mathrm{NgLj}-3$ (Fig. 2).

We know that Inuit interacted with Franklin expedition material at these three sites; however, no studies to date have tried to shed light on these behaviours. The result is an incomplete understanding of what occurred at $\mathrm{NgLj}-2$, $\mathrm{NgLj}-3$, and $\mathrm{NgLj}-8$ and a failure to explicitly acknowledge the active role of Inuit actors at these sites. In the journals of those sent to search for the missing Franklin expedition, Inuit were largely allotted a passive role as informants or guides (McClintock, 1860; Nourse, 1879; Gilder, 1881). However, they were also independent actors who made their own decisions about the material they found, and it is important that we highlight their contributions as completely as possible. This goal can be achieved by focusing on what happened to the two boats after they were abandoned by members of the Franklin expedition.

Schiffer $(1972,1987)$ was one of the first to identify the importance of closely examining how sites change over time and the processes that an artifact may go through during its lifetime. A number of subsequent studies have successfully

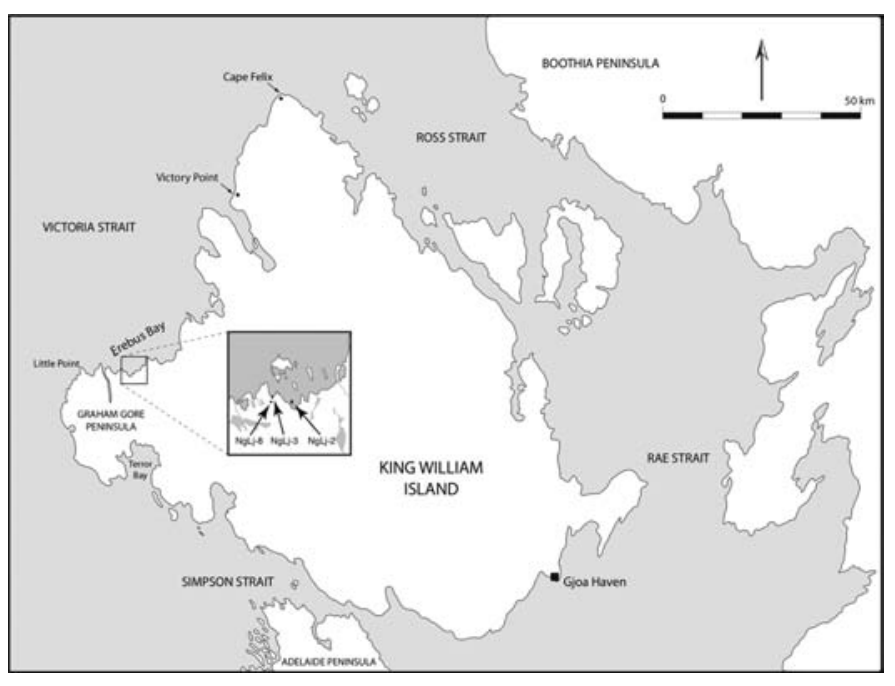

FIG. 2. Map of King William Island, with inset showing the location of sites $\mathrm{NgLj}-2, \mathrm{NgLj}-3$, and $\mathrm{NgLj}-8$ on Erebus Bay.

looked at how artifacts were either reclaimed or reused to understand what motivated that behaviour (Wilson, 1995; Amick, 2007; Swift, 2012; Seeb, 2013; Romagnoli, 2015). For example, some groups reused lithic material to make up for the lack of natural raw material in their area (Amick, 2007:244; Rios-Garaizar et al., 2015:194), and others constructed monuments in a manner that incorporated much older burial cairns to ensure the survival of those cairns (Bradley, 2002:77). Many intertwined variables determine how an individual interacts with his or her physical surroundings (Stahl, 2002; Hodder, 2012; Stockhammer, 2013), but this study will focus on how Inuit salvaged material abandoned by members of the Franklin expedition to reveal (1) how the extant environment influenced their behaviour, (2) what the material at these sites allowed Inuit to do, (3) what they wanted to use the material for, and (4) the past events that would have altered their actions at and perception of these sites. Together, these factors illustrate that the material abandoned by Franklin's men in Erebus Bay was incorporated into the Inuit material world and therefore must be labeled and recognized both as the remains of European boats and as Inuit repositories of wood and metal.

\section{BACKGROUND}

\section{Historical Accounts of $N g L j-2, N g L j-3$, and $N g L j-8$}

The first to discover and record the site now known as $\mathrm{NgLj}-3$ was Lieutenant William Hobson, secondin-command to Captain Leopold McClintock. While searching the shoreline of Erebus Bay on 24 May 1859, he found a 28 -foot pinnace (Fig. 3) partially dislodged from the heavy sledge on which it was sitting (Cyriax, 1939:165; Beattie and Geiger, 1988:38). Inside the boat, he found the remains of two individuals, as well as a large number 
of artifacts. These artifacts, which were listed in detail in McClintock's report, included three axes, files, saws, knives, dishware, clothing, paddles, two rolls of sheetlead, guns, and ammunition (McClintock, 1860:266-267; Stenton, 2014a:518). McClintock arrived at the boat six days later (McClintock, 1860:255), and in his own description of the site, he notes the same features recorded by Hobson and adds that while the boat had originally been built in carvel fashion (with the strakes attached to the ribs edge-to-edge), the upper strakes had been removed and replaced by thin fir planks in clinker fashion (with the strakes overlapping and attached to each other) in order to lighten the load (McClintock, 1860:263). On the basis of the undisturbed nature of the site, Hobson determined that Inuit had not yet found the boat (Cyriax, 1939:176; Stenton, 2014a:517). These explorers then altered what was available to Inuit who arrived in Erebus Bay after Hobson and McClintock's initial discovery by removing a number of artifacts from the boat site (McClintock, 1860:334-336).

The next account we have of the boats in Erebus Bay comes from the journal of Charles Francis Hall, who led a search for survivors of the Franklin expedition from 1864 to 1869. Although Hall did not visit Erebus Bay himself, he recorded descriptions of the sites from an Inuit informant, In-nook-poo-zhe-jook, who by Hall's calculation had visited the boats in spring 1861 (Nourse, 1879:416; Woodman, 1991:299; Stenton and Park, 2017:207). In-nook-poo-zhejook's testimony is the first record we have of a second boat in Erebus Bay east of the one described by McClintock (Nourse, 1879:405; Cyriax, 1939:177), and although he reported that one boat was empty (which he stated was the boat that Hobson and McClintock had found), the second had apparently not yet been disturbed (Nourse, 1879:405). In-nook-poo-zhe-jook and his accompanying party were therefore likely the first people to arrive at these boats after Hobson and McClintock. The second boat was described as being copper-fastened, with many skeletons in and around it, and with a tent and hearth nearby (Nourse, 1879:420). However, even though the only other boat place known archaeologically is $\mathrm{NgLj}-2$, significant discrepancies exist between the archaeological record and In-nook-poo-zhejook's description of the site. These discrepancies have not been resolved, and a recent analysis suggests the possibility that In-nook-poo-zhe-jook was describing a third, as yet undiscovered, boat site in Erebus Bay, or that certain aspects of his testimony were embellished (Stenton and Park, 2017).

The last important historical record of the boats in Erebus Bay discussed here is found in Lieutenant Frederick Schwatka's 1878-80 written account of his search for records from the lost expedition. When Schwatka arrived at the boat sites in July 1879, he found discarded pieces of a clinker-built boat, a boat stem, a broken gunwale, and other miscellaneous artifacts left behind by Inuit (Gilder, 1881:155-156; Schwatka, 1965:88; Klutschak, 1987:94). He and his party buried 76 human bones here (Gilder, 1881:156; Klutschak, 1987:94), and these were recovered during archaeological investigations in 2013 (Stenton, 2014b:9). We can therefore confirm that what archaeologists have termed $\mathrm{NgLj}-3$ is the same boat site that Schwatka found (Stenton et al., 2015:34; Stenton and Park, 2017:209). Furthermore, the boat stem recovered by Schwatka and returned to the National Maritime Museum (NMM) bears the same markings as the boat stem described by McClintock (Stenton and Park, 2017:210), confirming that McClintock and Schwatka had found the same boat. Schwatka was aware that Inuit had reported a second boat site in the area, but he was not able to locate it (Gilder, 1881:157; Schwatka, 1965:88).

\section{Netsilik Inuit}

During the latter half of the 19th century, Netsilik Inuit occupied a region of the Central Arctic that included King William Island, the Boothia Peninsula, and the Adelaide Peninsula (Balikci, 1970:xvii). It would have been Netsilik that found and dismantled the boats in Erebus Bay, and therefore, it is important to understand their material culture and lifestyle if we are to interpret their behaviours at $\mathrm{NgLj}-2, \mathrm{NgLj}-3$, and $\mathrm{NgLj}-8$. The Netsilik were seasonally mobile, hunting seal at breathing holes in the winter and caribou in the summer and fall (Balikci, 1970; Damas, 1988:102). Fish also played an important part in the Netsilik diet, and occasionally small animals and birds were trapped or shot (Balikci, 1970; Rasmussen, 1976). During the fall and winter months, the Netsilik would aggregate in relatively large snow house villages, but when they dispersed across the landscape in smaller groups during the spring and summer, they used light skin tents (Balikci, 1970:4-5; Damas, 1988:102). This lifestyle required a large array of implements, and each of these would have traditionally been constructed out of stone, bone, and other animal products. These same tools were also constructed out of wood and metal when these resources were available, and the boats at Erebus Bay would have served as an excellent source of both.

Wood and metal are valuable and rare resources in the Arctic (Balikci, 1970:xxii; Rasmussen, 1976:145; Savelle, 1981; Hickey, 1984:19), and numerous explorers noted how well these materials were received by the local Inuit population (Lyon, 1824; Parry, 1824; Ross, 1835; McClintock, 1860; Nourse, 1879; Schwatka, 1965). However, it is important to note that neither wood nor metal was unknown to Inuit prior to European exploration in the region. Driftwood, although rare, was also collected, and McClintock (1860:264) reports finding a 12-foot-long fir tree stump in Erebus Bay in 1859, so driftwood clearly was available, if not predictably, in the region where the boats were abandoned. Native copper and, to a lesser degree, meteoritic iron were also in use many years before European arrival (McCartney and Mack, 1973; Morrison, 1987; Pringle, 1997:767). At some Paleo-Inuit sites, the use of such materials appears relatively widespread (Pringle, 1997:766). The western neighbors of the Netsilik, the 
Inuinnait (also known as the Copper Inuit), made extensive use of native copper deposits in the region (Morrison, 1987), and it is very possible that trade took place between these two groups.

Furthermore, the Netsilik who dismantled the boats in Erebus Bay had already come in contact with European material prior to this interaction with materials from the Franklin expedition. Captain John Ross was forced to abandon the malfunctioning engine of his ship, as well as a smaller boat, the Krusenstern, in the Netsilik region during his 1832 search for the Northwest Passage, (Savelle, 1985:195). He also left a stores depot near the Boothia Peninsula, along with his ship, the HMS Victory, when the ship became locked in ice (Ross, 1835:643; Cyriax, 1939:10; Berton, 1988:117; Damas, 1988:104). Given that Ross exchanged goods and services with Netsilik during his time there, they would have known where the ship was abandoned, and Hall even notes that in the 1860s, he encountered some individuals with a sledge made from pieces of HMS Victory (Nourse, 1879:261). There is also evidence that Inuit reduced and removed a considerable portion of the engine and the boiler (Larsen, 1984:17; Savelle, 1985:196). The Inuit were therefore very familiar with European material, having encountered Ross's abandoned ship and the goods he left behind possibly 30 years before In-nook-poo-zhe-jook found the boats in Erebus Bay.

Inuit oral testimony also confirms that Netsilik had already discovered and used a wide range of materials they had found at Franklin expedition sites in other locations (Nourse, 1879; Schwatka, 1965). These included a boat on Adelaide Peninsula in Starvation Cove, as well as a boat near Point Ogle and Montreal Island (Rae, 1855:16; McClintock, 1860). It is therefore likely that In-nook-poozhe-jook was already familiar with how European material and specifically, European boats, could be re-used before his arrival in Erebus Bay.

\section{Archaeological Investigations at $\mathrm{NgLj}-2, \mathrm{NgLj-3}$ and} $\mathrm{NgLj}-8$

The first archaeological search for the Franklin expedition boats in Erebus Bay dates to 1982, when Owen Beattie found the scattered remains of a boat at what is now labeled NgLj-1. In 1992, amateur historian Barry Ranford discovered NgLj-2. Archaeologist Margaret Bertulli began excavations at $\mathrm{NgLj}-2$ the following year (Stenton and Park, 2017:209), and while participating in Bertulli's excavation, Ranford discovered NgLj-3, which archaeologist John MacDonald mapped in 1994 (Stenton and Park, 2017:205). The most recent investigations at $\mathrm{NgLj}-2$ and $\mathrm{NgLj}-3$ were conducted by Douglas Stenton and Robert Park from 2012 to 2015. Although this study focuses on the boat remains collected from these sites, a variety of other artifacts, including cloth fragments, percussion caps, buttons, and personal effects, were also found. In addition to artifacts, human skeletal remains were recovered. While a minimum number of 11 individuals was originally estimated for NgLj-2 (Keenleyside et al., 1997:38), recent DNA studies have increased this estimate to 13 individuals (Stenton et al., 2017:7). At $\mathrm{NgLj}-3$, bioarchaeological studies indicate that the recovered remains come from three individuals (Stenton et al., 2015:40).

An Inuit tent ring and artifacts associated with the Franklin expedition were also discovered at $\mathrm{NgLj}-8$, situated $365 \mathrm{~m}$ SSW of NgLj-3 (Stenton, 2014b:10). Investigations were conducted at the site in 2013, 2014, and 2015 and, given that a significant number of the artifacts unquestionably originated from a Franklin expedition boat, it appears that the Inuit had moved some material from one or more of the boat sites to this location.

\section{METHODS}

For the purpose of this study, 644 wood artifacts and 192 metal artifacts (124 nails and bolts, 65 roves and 3 iron knees) were analyzed. These artifacts were recovered during the 1993, 2012, 2013, 2014, and 2015 investigations at $\mathrm{NgLj}-2, \mathrm{NgLj}-3$, and $\mathrm{NgLj}-8$ and are part of the collection of the Government of Nunavut. It is important to note that the collection examined is a subset of the material that archaeologists encountered and that not all of the artifacts found at these sites were recovered in excavation. This collection is therefore assumed to be a representative sample of the entire assemblage. During creation of the database for these items, each artifact was catalogued and examined for attributes that might pertain to Inuit use of the material (see Table 1).

Once the unmodified driftwood was removed and the recently broken wood that could be refitted was reduced to a single catalogue entry, the number of wood fragments that remained was 594. Along with the features mentioned in Table 1, each artifact was also examined for other signs of Inuit activity that were too infrequent to include in the description of each individual piece. These signs were analyzed separately. Once each artifact was catalogued, the frequency of each feature was calculated and examined together with the comments on individual artifacts to reveal what influenced the Netsilik's behaviour at these three sites.

\section{RESULTS}

\section{Absent Material}

The material left behind at $\mathrm{NgLj}-2, \mathrm{NgLj}-3$, and $\mathrm{NgLj}-8$ is what the Netsilik discarded over multiple extraction events, not what they selected for. Therefore, it is important for us to consider what went missing over time, as well as what was left. Archaeologists have tried to avoid making interpretations based on what is absent because the past condition of a site is often poorly documented, making it difficult to determine what has gone missing (Stone, 
TABLE 1. Attributes measured on artifacts recovered from $\mathrm{NgLj}-2, \mathrm{NgLj}-3$, and $\mathrm{NgLj}-8$

\begin{tabular}{|c|c|c|}
\hline & Feature & Information recorded \\
\hline \multirow[t]{8}{*}{ Wood } & Dimensions & - Length in centimetres \\
\hline & Ends and faces ${ }^{1}$ & $\begin{array}{l}\text { - Broken, recently broken, }{ }^{2} \text { sawn, rounded, burnt, or driftwood }{ }^{3} \text { (driftwood was subsequently removed } \\
\text { from analysis if no other features were indicative of Inuit use) }\end{array}$ \\
\hline & Nail holes & • Number \\
\hline & Nails & - Number \\
\hline & & - Included in nail analysis (see below) \\
\hline & Refit & - Artifact number of fragment it refits with \\
\hline & Body & - Wood broken up to saw mark or not \\
\hline & & - Wood bent in an effort to break it or not \\
\hline \multirow{6}{*}{ Nails and bolts } & Material & - Copper or iron \\
\hline & Shank & - Round, square, or indeterminate in cross section \\
\hline & Completeness & - Head missing, tip missing, unknown, or none \\
\hline & Property mark & - Broad arrow, no broad arrow, or it could not be determined \\
\hline & Size of shaft & - Small $(<0.5 \mathrm{~cm})$, medium $(0.5-1 \mathrm{~cm})$, or large $(>1 \mathrm{~cm})$ \\
\hline & End & - Complete, broken, cut, or indeterminate (if the nail was still embedded in the wood) \\
\hline \multirow[t]{5}{*}{ Roves } & Type & - Round or square \\
\hline & Material & - Copper or iron \\
\hline & Completeness & - Broken or not \\
\hline & Nail hole & - Square, round, or indeterminate in cross-section \\
\hline & Nail still in rove & - Included in nail analysis (see above) \\
\hline
\end{tabular}

${ }^{1}$ Each wood fragment was orientated so that the artifact number was upright and facing the researcher (face 1) and subsequent faces were numbered after the top of the artifact was rotated towards the researcher.

${ }^{2}$ If two wood fragments were recently broken (identified by a difference in colour when compared with the other faces) and could be refit together, they were included as one entry in the catalogue.

${ }^{3}$ For wood that was triangular in cross-section, face 4 was labeled as not applicable (NA). For wood that was very thin and had only two discernible faces, or for fragments that were semi-circular in cross-section, faces 2 and 4 were labeled NA.

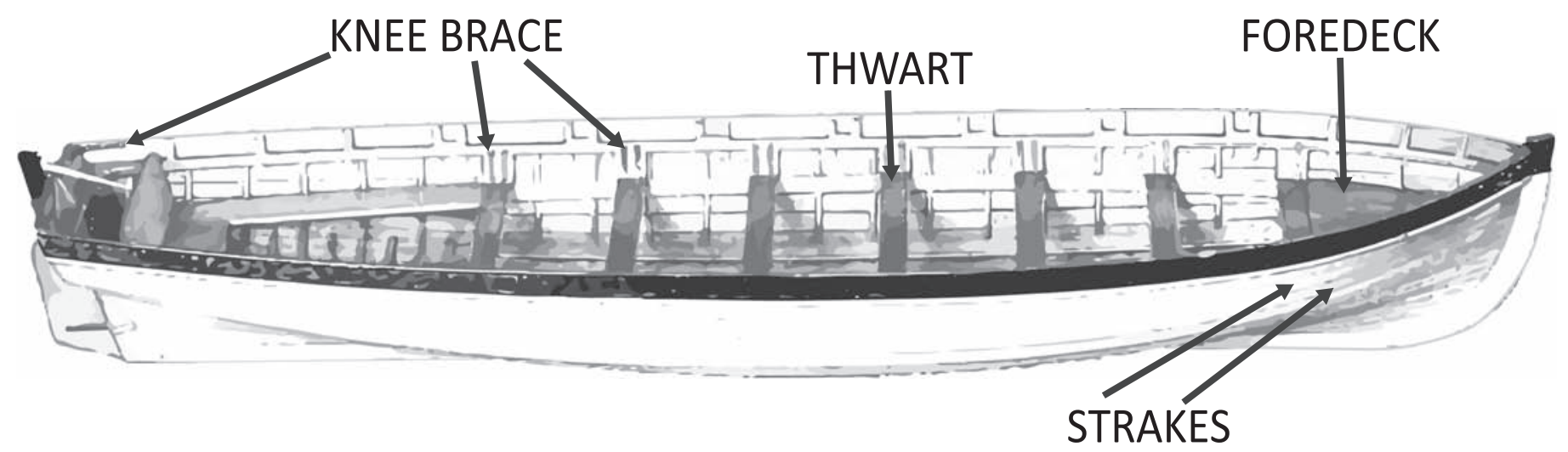

FIG. 3. Diagram of pinnace (redrawn after Royal Museums Greenwich, 2018b).

1981:81; Gowlett and Wrangham, 2013:10). Luckily, we have detailed records of $\mathrm{NgLj}-3$ prior to its deconstruction that we can use to better assess what material was removed by Inuit.

What McClintock and Hobson found at $\mathrm{NgLj}-3$ was a 28-foot pinnace on top of a 23-foot long, four-inch deep sled that McClintock estimated to weigh around 1400 pounds (McClintock, 1860:263; Beattie and Geiger, 1988:39; Stenton, 2014a:514). On this boat alone, there would have been hundreds of nails present and enough outer planking to cover a boat 28 feet in length, 7.5 feet wide, and 2.5 feet deep (Stenton 2014a:518). There would have also been eight thwarts for the rowers inside the boat as well as decking at both the bow and the stern. The sled the boat was resting on, in addition to being 23.3 feet long, was also two feet wide and had five oak crossbars and five fir chocks to support the vessel (Stenton, 2014a:518). Unfortunately, we cannot estimate the amount of wood and metal that would have been available to Inuit at $\mathrm{NgLj}-2$ because we do not know what boat was abandoned there; however, a simple comparison of the existing archaeological record with what was available at $\mathrm{NgLj}-3$ alone clearly indicates that the vast majority of the wood and metal had been removed by the time archaeologists arrived in Erebus Bay. In particular, the long pieces of wood that were used to construct the outer shells of each boat had been largely removed when Schwatka found the boat at $\mathrm{NgLj-3}$ in 1879 and were entirely gone when archeologists arrived at the sites (Fig. 4). In fact, the average length for all of the wood studied was $12.5 \mathrm{~cm}$, and the longest length was only $47 \mathrm{~cm}$. 


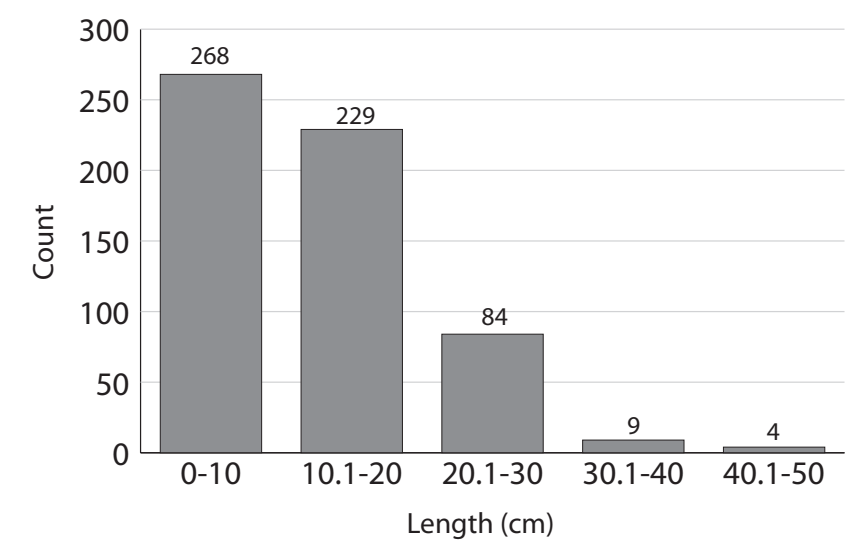

FIG. 4. Length $(\mathrm{cm})$ of the 594 wood fragments recovered.

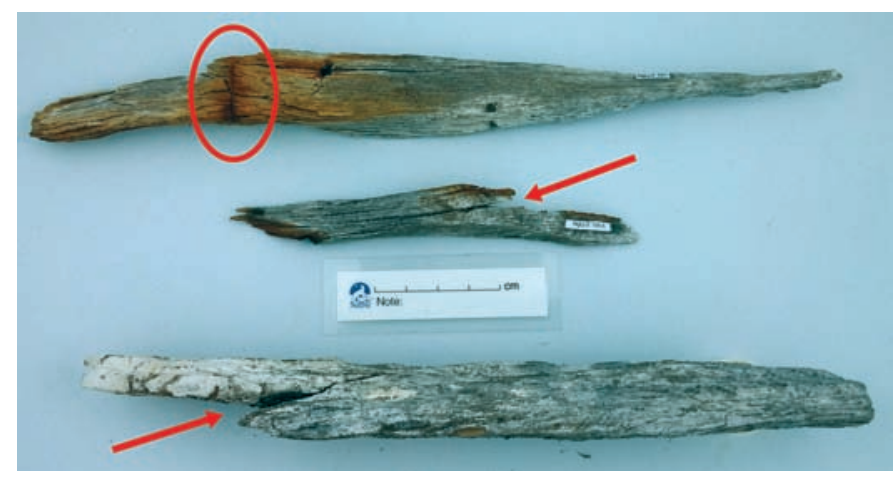

FIG. 5. Wood fragments with bending stress failure indicated.

A number of the knee braces that would have held up the thwarts and other structural elements of the boats were also missing from the site. According to a model from the National Maritime Museum of a 19th-century 28-foot pinnace, the boat at $\mathrm{NgLj}-3$ would have had at least 28 iron knee-braces (four for each thwart, two on the foredeck, and two at the stern) and likely more such braces supporting other structural elements of the boat (Royal Museums Greenwich, 2018b). The boat at $\mathrm{NgLj}-2$ would have also been constructed with iron knees, but we do not have any information regarding what type of boat it was. That being said, we do know that a 12-foot dinghy was the smallest boat that HMS Terror and HMS Erebus were equipped with (Winfield, 2014:280) and that a 30-foot galley and a 30 -foot whaleboat were the largest. Construction plans from the 19th century and a reconstruction of this boat in the National Maritime Museum collection indicate that a 12-foot dinghy had two thwarts (Winfield, 2014:246) and at least eight iron knees to support them. The 30-foot galley (which had more knee braces than the whaleboat) had six thwarts with four knee braces to support each, two knee braces on the foredeck, and four near the stern (Royal Museums Greenwich, 2018a). Therefore, although it is unlikely that the members of Franklin's crew would have abandoned their smallest boat this early in their trek, there would have been between 36 and 58 knee braces available at these boat sites, and the fact that only four were

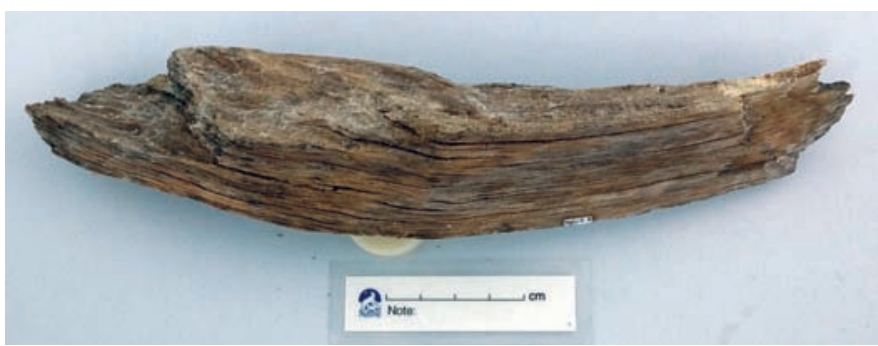

FIG. 6. Fragment illustrating wood bent during construction.

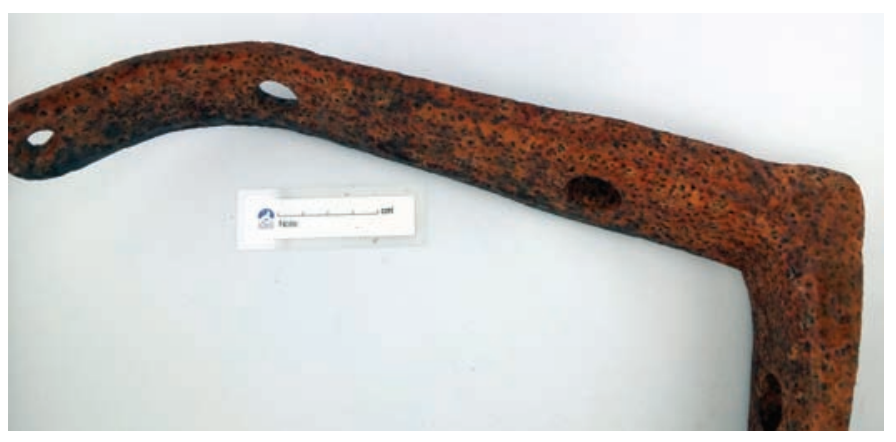

FIG. 7. Iron knee with arm bent at the end.

recovered (Barry Ranford found a fourth in the area, but his find was not included in the study) indicates that many were removed for some purpose.

\section{Evidence of Bending}

Among the wood and metal artifacts left behind by the Inuit, there is evidence that the boards of the boat were bent in an attempt to break them. Whether these actions were performed after Inuit had already removed the boards from the boat or while they were still attached is uncertain, but 56 of the 594 wooden fragments that were recovered display characteristics of bending force failure. When pressure is applied at a single point on a wooden beam, longitudinal stresses are created on the face opposite where the pressure is applied (Kollmann and Côté, 1968:544; Ennos and van Casteren, 2010:1253). This causes a predictable pattern of failure, as demonstrated by three-point stress tests, in which the wood splinters along its length. We see this same failure pattern in 56 of the wooden pieces left behind by Inuit at $\mathrm{NgLj}-2$ and $\mathrm{NgLj}-3$ (Fig. 5). During the construction of the boat, the carpenters would have had to bend the wood to attach it to the frames of the vessel; however, they would have used heat, likely in the form of steam, to aid in this process (Holland, 1971:31; McKee, 1983:59). If the wood is bent in this fashion, it retains a smooth surface through the bend (Kollmann and Côté, 1968:542) that is devoid of cracks (Fig. 6).

One of the wrought iron knee braces recovered at $\mathrm{NgLj}-8$ also displays evidence of bending. The knees held together structural elements of the boats at $\mathrm{NgLj}-2$ and $\mathrm{NgLj}-3$ and were fastened to the wood with iron bolts (Stammers, 2001:115; Moss, 2006:81). Although they were bent during 


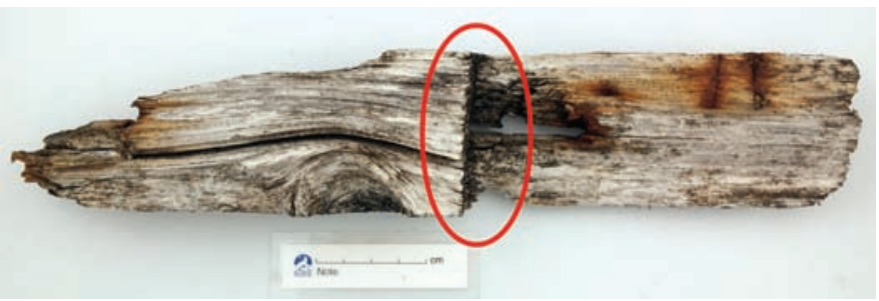

FIG. 8. Wood fragment broken up to saw mark (circled) with nails removed from broken section (to the right of the saw mark).

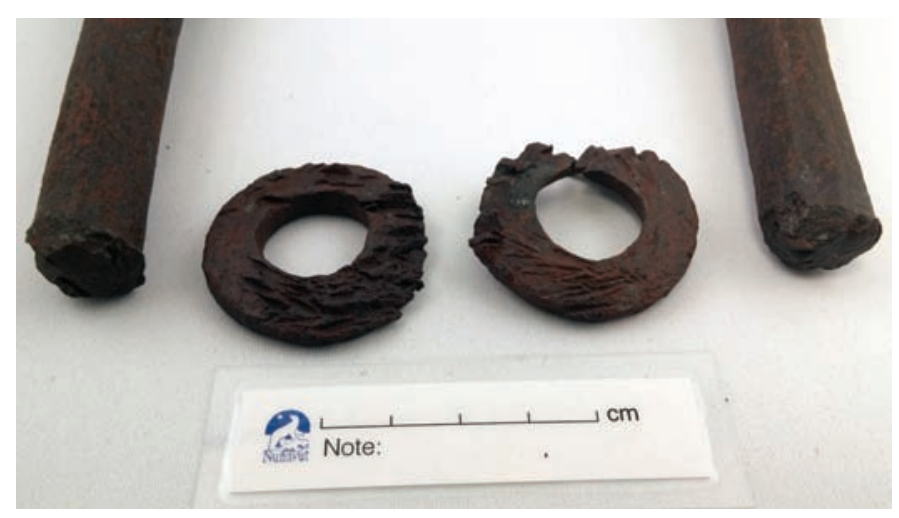

FIG. 9. Bolts and clinch rings with chop marks.

construction to fit the features of the vessel (McCarthy, 2005:74; Moss, 2006:88), the arm of $\mathrm{NgLj}-8: 1$ does not appear to have been modified for this purpose. Instead of the relatively uniform bend we would expect if the arm followed the curvature of the vessel, this knee brace is bent much more drastically and only at the end (Fig. 7). This drastic bend suggests that, using the boards of the boat as leverage, Inuit bent the knee brace while it was still affixed to the vessel. Had they tried to bend the brace once it was removed, a hammering tool or a fulcrum would have been required, and there are no marks on the artifact to indicate that either was used.

\section{Use of European-Manufactured Tools}

There is also evidence that Inuit used European tools to dismantle the boats. McClintock and Hobson reported that three axes, as well as a broken saw, were found at the boat they discovered ( $\mathrm{NgLj}-3$ ) (McClintock, 1860:267; Stenton, 2014a:518), and these tools were listed as having been left at the site (McClintock, 1860:335). Marks from these same tool types were discovered on artifacts collected from all three sites. Although Franklin's crew had previously altered the boat at $\mathrm{NgLj}-3$ and in so doing likely caused some of these marks (McClintock, 1860:263), Inuit appear to have been responsible for some as well.

Of the 594 wood fragments, at least 32 were broken along the grain up to a saw mark running perpendicular to the broken edge, and on one fragment, there are nail holes in the broken section (Fig. 8). It is unlikely that Franklin's crew broke the wood in this fashion because, if the nails were removed, the plank would not have been structurally

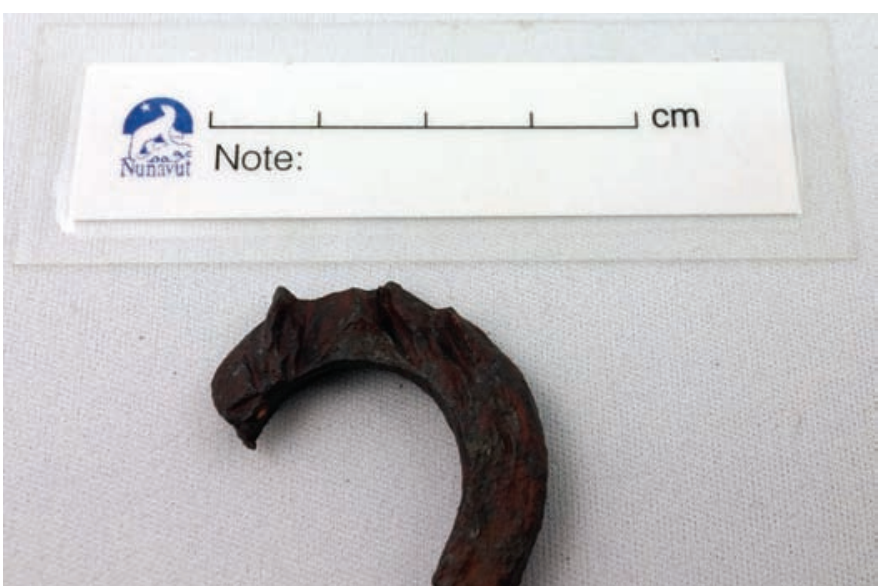

FIG. 10. Detail of clinch ring depicting hinged metal as result of adze strike.

integral to the vessel and therefore would have been abandoned where the alterations were made before the boat was dragged away from the ships. It has also already been demonstrated that Inuit were bending and breaking parts of the boat and that saws would have been available at $\mathrm{NgLj}-3$ and via trade with McClintock (McClintock, 1860:146). These lines of evidence suggest that it was Inuit who were responsible for at least some of these saw marks.

As well, there is evidence on the bolts and clinch rings recovered from $\mathrm{NgLj}-8$ that an adze, a pickaxe, or an axe was used to remove these from the wood. The bolts and clinch rings were used to attach the iron knee braces to the thwarts and to hold other structural elements of the boat together. The head of the bolt would rest against the iron knee, but to keep it from being pulled back through the hole, the end would have been hammered down and flattened over a clinch ring on the bottom of the thwart (McCarthy, 2005:91-92; Zori, 2007). Therefore, in order to remove the bolt, the clinch ring would need to be detached first. It appears that Inuit used an adze, pickaxe, or an axe for this task because every clinch ring and bolt recovered has chop marks (Fig. 9), and a number of them display a hinge feature (Fig. 10) that is consistent with those left behind by an adze (Best, 1977; Cunliffe, 2013:79). Unlike the axe, the adze features a transverse head and the tool is normally drawn towards the user during the reduction process, resulting in a transverse groove pattern (Best, 1977:333; Cunliffe, 2013:106). In fact, the adze frequently caused injuries to the legs of dockworkers while they were shaping timber for a ship's hull (Biddle, 2009:111). Therefore, when the stroke is angled steeply and is halted partway through the material, it leaves a hinge. The chop marks on the clinch rings are also very deep, suggesting that a European adze, pickaxe, or axe, or an adze constructed out of European material, was used. Even though adzes had traditionally been part of the Netsilik toolkit (Balikci, 1970:16; Rasmussen, 1976:496), they would have been tipped only with stone or a small amount of metal and would have lacked the weight required to make such deep incisions. Instead, a Europeanmanufactured tool, which features a much heavier metal 


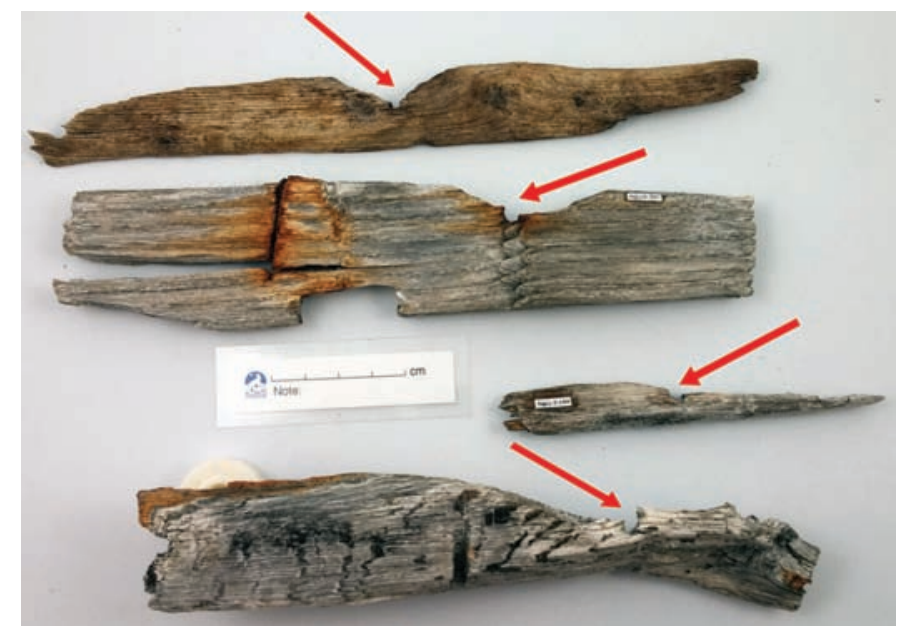

FIG. 11. Wood fragments with nail holes, showing cuts made from an edge down to a nail hole (presumably to aid removal of the nail).

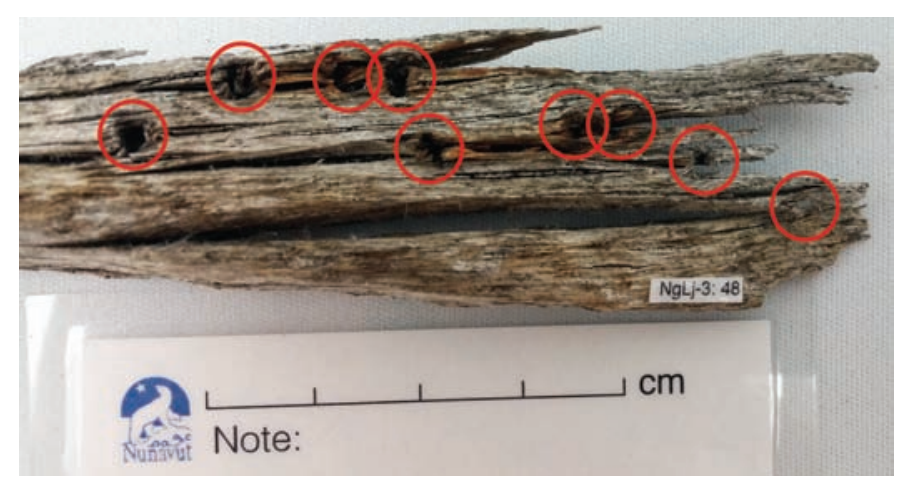

FIG. 12. Wood fragment with nine nail holes indicated.

head, was probably used, or an adze made from a large piece of metal. Hobson and McClintock listed every item they uncovered at the boat site, and an adze was not recorded in their reports. However, this tool was commonly used by carpenters (Samuel, 1977:37; Biddle, 2009), so it is possible that the Inuit picked one up at another location in Erebus Bay or at some other site associated with either Ross's or Franklin's expeditions.

\section{Nail Removal and Shaping}

On the 594 wood fragments, there were 400 nail holes and only 31 nails left embedded in the wood. In other words, $92.25 \%$ of the nails are missing, and even though nails may have been removed when Franklin's crewmembers altered the boats, the sheer volume of missing nails suggests that Inuit were responsible for removing at least some of them. There is also evidence suggesting that Inuit cut the wood apart in order to remove the nails. Four pieces of wood were recovered from $\mathrm{NgLj}-2$ and $\mathrm{NgLj}-3$ that have cut marks down to a nail hole (Fig. 11). The wood was then either discarded or forgotten at the site. Another possibility is that Inuit created some of these nail holes. One artifact has nine nail holes within a $6.0 \times 1.6 \mathrm{~cm}^{2}$ area (Fig. 12). Affixing nails close together, and particularly along the same

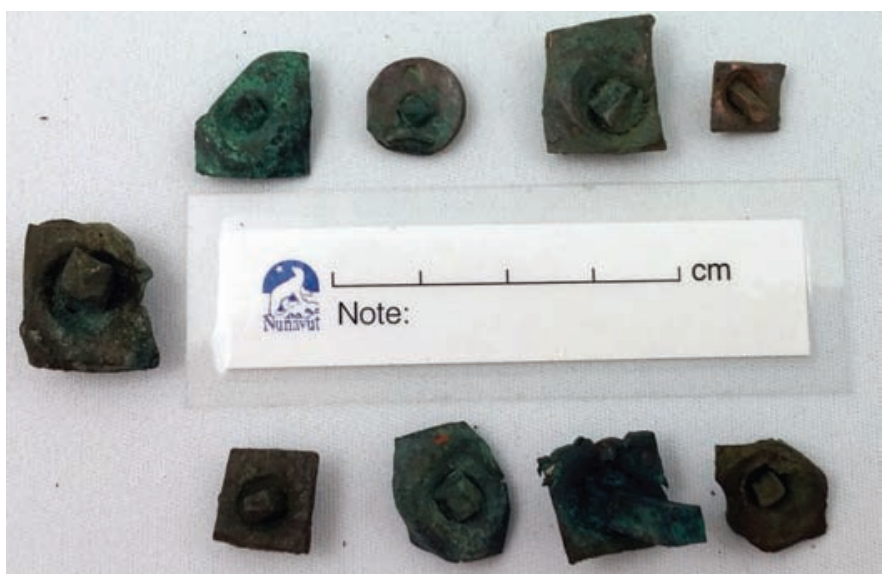

FIG. 13. Roves with nails still in them. Each nail was cut off just below the head.

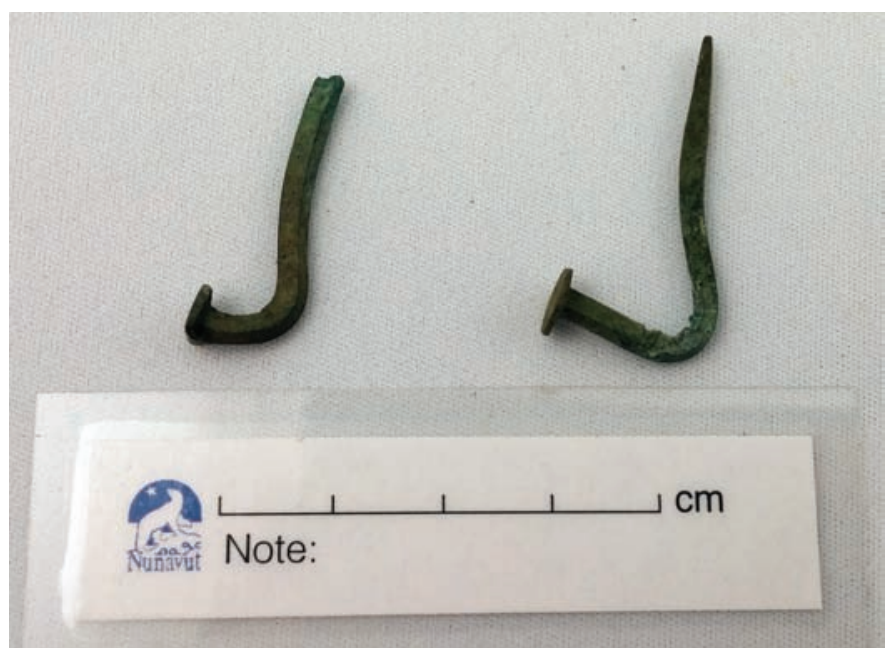

FIG. 14. Two recovered nails that have been bent into a J-shape.

grain, damages the structural integrity of the wood and increases the risk of splitting (McKee, 1983:48); therefore, it is unlikely that these nail holes were created during the construction process or when the boat was refitted to make it lighter. The Inuit were the only ones who altered the material after these events, so it is likely that they were the cause of this unique feature. That being said, there is nothing else in the archaeological record to corroborate this claim, and it is important only as a possible factor that may have exaggerated the nail hole count.

My research also suggests that Inuit put effort into removing the riveted nails. A riveted nail has a rove placed over its end and the end is deformed so that it cannot be pulled back through the hole (McGrail, 2004:151; Zori, 2007). This technique is common in clinker-built vessels (Hutchinson, 1984:31; Lavery, 1987:217) and would have been used to build the clinker-sections of the boat at $\mathrm{NgLj}-3$. The deformed nail end would have made it impossible to remove the nail without first cutting off either the nail head or the riveted end. Inuit evidently engaged in such activities because $32.05 \%(n=50)$ of all the nails recovered $(n=156)$ were cut on at least one end (Fig. 13). It also appears that 
Inuit tried to remove the rove by either prying it off or breaking it in a similar fashion as the clinched bolts. Of the used square copper roves $(n=39)$, excluding the single rove that was recovered still attached to the wood, $35.90 \%$ $(n=14)$ had at least one corner bent up, and of all the roves and clinch rings recovered $(n=54), 55.38 \%(n=35)$ were broken. Evidently, Inuit put time and effort into removing these riveted nails and bolts.

The Inuit also tried to shape some of the nails at $\mathrm{NgLj}-2$, and two nails recovered were bent into a J-shape (Fig. 14). Bent nails were not uncommon among the artifacts recovered from these sites; in fact, $36.54 \%(n=57)$ of all the nails recovered $(n=156)$ were bent. However, the cut marks in the bends of these two nails suggest that this was intentional shaping and not a consequence of pulling the nails out of the wood.

\section{DISCUSSION}

The results of this study allow us to make inferences concerning what influenced Netsilik behaviour at these sites. Their knowledge of the extant environment, material affordances, past events, and what they intended on using the material for were made visible during the salvage process and illustrate how archaeological artifacts allow us to reflect on the lives of all those that interacted with them. It must also be noted that each influential factor played a role in various parts of the salvage process, and therefore, this section is deliberately not divided by factor.

On the basis of In-nook-poo-zhe-jook's testimony, Hall calculated that Netsilik Inuit arrived at the Erebus Bay sites in the spring of 1861 (Nourse, 1879:416; Stenton and Park, 2017:207). This is an important point to stress because Netsilik practiced seasonal mobility to exploit seasonally variable resources and normally hunted caribou in the spring and fall. However, at that time, very few caribou were available in the northwestern region of KWI, and the Inuit seldom traveled there (Schwatka, 1965:44; Rasmussen, 1976:144-145; Damas, 1988:125; Woodman, 1991:189). In fact, one Inuit informant stated that the sole reason people were traveling to that part of the island was to obtain Franklin expedition wood, copper, and iron (Klutschak, 1987:74). We know that Inuit living in this region had already come in contact with other Europeans and, sometime between 1848 and 1859, with other boats left behind by members of the Franklin expedition south of KWI. They also knew, from what McClintock told them, that European explorers had traveled along the west coast of KWI, and on the basis of their knowledge about what valuable resources could be obtained from European sites, they decided to travel into the region. We can therefore state with some certainty that the presence of Netsilik Inuit at $\mathrm{NgLj}-2$ and $\mathrm{NgLj}-3$ reflects their own previous experience with European sites and their knowledge of both what resources could be salvaged there and what resources would be suitable for life in the Arctic.
That being said, the results of this study suggest that simply explaining Inuit salvage behaviour as a desire for wood and metal is not sufficient. The Netsilik who dismantled the boats at $\mathrm{NgLj}-2$ and $\mathrm{NgLj}-3$ and reduced the material further at $\mathrm{NgLj}-8$ were after rare wood and metal resources, and this purpose is reflected in the material missing from these sites (the majority of the iron knees, many nails, and a significant amount of wood), but the factors that motivated their behaviour were not necessarily straightforward. Inuit discarded four pieces of wood which they had cut down to a nail and removed it. This behaviour suggests that the metal was more important to them; however, wood was not always sacrificed in favour of metal, and $32.05 \%$ of all the nails recovered were cut on at least one end. These conflicting behaviours demonstrate that, although it is easier to cut through wood, the Netsilik did not always do so. Instead, Inuit individuals made efforts to preserve the metal over the wood in some cases, but they (or possibly other Netsilik visitors to the sites) also engaged in activities that would preserve the wood in others. These conflicting extraction methods could reflect individual differences regarding which resources should be salvaged. They could also reflect the fact that there was too much wood available at these sites for any one Inuit group to logistically transport, and therefore the dismantling of the boats in Erebus Bay took place over multiple visits. In fact, Schwatka and company recorded several long pieces of wood that the Inuit had left behind at $\mathrm{NgLj}-320$ years after McClintock first arrived at the Erebus Bay boat sites (Gilder, 1881:156; Schwatka, 1965:88). Evidently, there was enough highly desirable wood available at these sites that pieces of it were still available for a relatively long time after the boats were found. These long pieces of wood had been removed by the time archaeologists arrived at the site, suggesting that Inuit continued to remove materials from $\mathrm{NgLj}-3$ after 1879 . If so, it is likely that different groups were responsible for employing different salvaging strategies in response to the material that was available to them at the time.

The results of my research also support both of the following conflicting conclusions: that the Netsilik used European tools to dismantle the boats and that Europeanmanufactured tools were not used in the dismantling of the boats. The tool marks recorded suggest that the Inuit used a European saw and either an adze of European manufacture, an adze made from European material, a pickaxe, or an axe. However, archaeologists also recovered wood that displays evidence of Inuit having bent it in an effort to break it, and one of the knees appears to have been bent while still affixed to the wood. Therefore, even though heavy tools of European manufacture that might have made the dismantling process easier were available to them, the Netsilik did not invariably use them. These conflicting extraction methods could also be the result of different Inuit groups using different extraction methods over time. Indeed, it is very likely that the first people to find the boats removed the tools that McClintock had left there, and these 
tools would not have been available to subsequent groups. It is also possible that there were not enough European tools recovered for every person to have one, so that those who did not have a European axe, saw, or adze used other means to break apart the wood. Finally, one should not assume that European-manufactured tools were necessarily superior; perhaps it was easier to pry apart the boat once an effective handhold could be established. In fact, given that $99.67 \%$ of the wood recovered had at least one broken edge, it can be assumed that breaking the wood was an effective extraction method.

The length of the wood recovered in the current archaeological record also suggests that Inuit who salvaged these boats were influenced by the volume of material abandoned at these sites, as well as by what their intentions were for the material. As previously mentioned, the long planks of the boat were not recovered by archaeologists, and this is likely because wood of that size would have been useful for making harpoons for seal-hunting, leisters for fishing, bows, arrows, spears, tent poles, kayaks, sleds and other wood-intensive items (McClintock, 1860; Nourse, 1879; Rasmussen, 1976). The lower boards (at least on the boat at $\mathrm{NgLj}-3$ ) were also made of strong mahogany that would have been highly suitable for constructing a variety of implements. Of course, the small pieces of mahogany and other types of wood were also useful, but the reduction of the longer pieces would have produced smaller pieces of wood for those implements (such as the handles of knives or harpoon rests) that required such material. It was therefore less important for Inuit to gather all of these smaller pieces; nor was it practical, given the number of small pieces of wood that would have been available. The fact that a number of small pieces of wood were still recovered in excavation indicates that the sheer amount of wood available diminished the importance of these smaller pieces. In this manner, the volume of wood and metal itself afforded certain ways of interacting with the material. The Inuit did not try to collect every bit of wood and metal available simply because it is rare in the Arctic; instead, they were influenced by the amount of material that was available to them at these sites.

The methods Netsilik used to salvage and shape the nails from these two boats also reflect their familiarity with how these materials could be used in the creation of Inuit tools. According to ethnographic evidence, iron nails could be flattened and used as projectile points or blades (McCartney and Mack, 1973:336) or hafted onto a handle as an ice pick (Balikci, 1970:7). Copper and iron nails could also be used as rivets to hold the wooden pieces of a tool together (McClintock, 1860:338; Balikci, 1970:18; Walpole, 2017:152) or they could be bent into fishhooks (Balicki, 1970:87). In fact, the two nails recovered that had been shaped by the Inuit were bent to resemble a fish hook, and it is possible that Inuit were trying to create this tool on site. That being said, it is also possible that these shaped nails were subsequently discarded, in which case we can assume that the achieved shape was not what was desired.
My research has also demonstrated that the Inuit cut off the riveted ends of nails to remove them from the wood. This effort, combined with the fact that $92.25 \%$ of the nails are missing, suggests that the Inuit were aware of the multiple purposes nails could serve and therefore put a significant amount of effort into removing them.

The missing knee braces may also have been removed because they could be reduced to make metal implements. Although the knees were made of brittle hand-forged iron and could not be worked as easily as other European metal (such as barrel hoops) to construct blades, harpoon tips, arrowheads, or adze heads and tips (McClintock, 1860; Nourse, 1879; Balikci, 1970; Rasmussen, 1976), the fact that so many were removed suggests that the Netsilik did find them useful. Studies of metal use prior to European arrival in the Arctic have proven that the Inuit reduced meteoritic iron (McCartney and Mack, 1973; Wayman, 1989:95; Pringle, 1997:767; Colligan, 2017), and although we do not have direct evidence of this behaviour in the Netsilik region of the Arctic, meteoritic iron artifacts were discovered near KWI (Colligan, 2017:112). Some Netsilik also had files, given to them by explorers or found at European sites, with which to work the metal (Ross, 1835; McClintock, 1860:339), and files were even found by McClintock and left at the boat site (McClintock, 1860:336). Therefore, the Inuit likely removed the knee braces because they knew how to reduce them to useful smaller pieces and had the tools to do so.

Inuit extraction processes were also influenced by their past experiences with European tools and what those tool types allowed their users. McClintock noted that saws were highly sought out in trade with Inuit and that they would use them to take apart "old wrecks" (McClintock, 1860:140, 151). However, there are no tools in the traditional Netsilik toolkit that resemble saws; therefore, it was only with the arrival of Europeans in the Arctic that this tool type became available. The saw itself allows wood (and other materials such as whalebone) to be cut in a controlled manner, and had Inuit not either found a saw at a European site or received one via trade, they would not have been able to interact with the boats in the manner my research suggests. In terms of the chopping tools, the adze was a part of the Inuit toolkit prior to European arrival in the Arctic (Rasmussen, 1976:496) and it can be assumed that they would know how to use one whether it was of European manufacture or not. The knowledge of how to use an adze could also be extended to the axe or the pickaxe, which are similar chopping tools, and the Inuit groups who dismantled the boats did have access to axes. McClintock and Hobson found three axes at $\mathrm{NgLj}-3$ and listed them as having been left on site (McClintock, 1860:335). Ross (1835:383) mentions having had an axe stolen, and European explorers may have traded axes with the Netsilik. My research suggests that the clinch rings were removed from the bolts via a heavy metal chopping tool, and the only tools that match this description are either of European construction or made from European raw material. Therefore, it was through contact with Europeans that Inuit were able to 
remove the clinch rings without having to go through the wood, and it is what the tools themselves allowed the user to do that facilitated their use in how Netsilik salvaged these two boats.

\section{IDEAS FOR FUTURE RESEARCH}

Deconstruction of the boats in Erebus Bay would likely have resulted in the construction of a number of different tools and implements that have not yet been recovered. The National Maritime Museum collection includes Netsilik tools that were recovered from groups around King William Island and are believed to be made from Franklin expedition material, but none of these artifacts have been definitively traced back to the boats in Erebus Bay. Archaeological investigations around KWI have also failed to uncover the large amount of material removed from these boats; therefore, it is likely that this material is widely dispersed. That being said, the boats in Erebus Bay represent only a fragment of the material left behind by the Franklin expedition. Although it is beyond the scope of this paper to assess the role that the entire Franklin expedition played on Netsilik material culture, it would be beneficial to compare Netsilik material culture prior to the arrival of the expedition to the existing ethnographic and archaeological data that post-date that arrival for evidence of material continuity and change.

Another potential avenue of study that is not explored in this paper is the effect of the remains of the Franklin expedition on Netsilik subsistence patterns. It is difficult to assess with accuracy how visits to Erebus Bay detracted from subsistence-related activities because we do not know how much time was allotted to visiting and deconstructing the boats, nor do we know how many people traveled there. However, Netsilik did travel into this region of King William Island for the sole purpose of extracting material left behind at these boat sites, and it may be fruitful to examine how the remains of the Franklin expedition, as a whole, similarly altered Netsilik subsistence patterns.

\section{CONCLUSION}

Inuit visited the sites in Erebus Bay on multiple occasions between 1859, when the initial discovery of a boat at Erebus Bay was made by Hobson and McClintock (McClintock, 1860:263; Stenton, 2014a) and 1982, when archaeologist Owen Beattie found the scattered remains of a boat in the region (Stenton and Park, 2017:215). The history of these sites is thus irreversibly entangled with the history of Inuit who traveled to King William Island to collect wood and metal from these boats, and it is important that we recognize the role that they played in constructing what we see in the archaeological record today.

On a broad scale, the strategies employed by the Inuit at $\mathrm{NgLj}-2, \mathrm{NgLj}-3$, and $\mathrm{NgLj}-8$ portray a combination of motives that sometimes appear to be conflicting. However, as Hodder (2012) points out, humans generally use material in a coherent manner that follows intertwined patterns of logic. The Inuit did not act illogically at these sites, but their behaviour is so complex that it cannot be captured in a single over-arching pattern. Instead, their alteration of the two boats while salvaging material from them was guided by a combination of their knowledge of what they could find at a European site, their previous encounters with Europeans and their technology, the paucity of wood and metal resources in the Arctic, the resources that different groups had available to them when they visited the boats, the types of actions that the European tools and material afforded, and what each group that visited these sites wanted to use the wood and metal for. Guided by these influential factors, Inuit irreversibly altered the boats to fit within their own knowledge system in the same way that Amerindians iconized European beads (Turgeon, 2004), the Tsimshian knapped broken glass (Martindale, 2009), and Marquesans equated guns to spears and clubs in certain ritual contexts (Thomas, 1991). This alteration imbued the boats with meaning outside of what those who originally constructed them ever intended and redefines the remains of the boats in Erebus Bay as simultaneously Netsilik and European material.

\section{ACKNOWLEDGEMENTS}

This research was completed at the University of Waterloo and was funded by the Government of Nunavut Department of Culture and Heritage, Nunavut Archaeology Program, the Social Sciences and Humanities Research Council of Canada, and the families of Iris Yuzdepski and Sally Weaver. I would also like to thank Robert Park, who provided valuable suggestions throughout this research and constructed the image of the pinnace used in Figure 3. Finally, I am grateful to Christopher Watts, Douglas Stenton, Rachel ten Bruggencate, and Melissa Pynkoski for their insightful comments on earlier drafts of this paper.

\section{REFERENCES}

Amick, D.S. 2007. Investigating the behavioral causes and archaeological effects of lithic artifact recycling. In: McPherron, S.P., ed. Tools versus cores: Alternative approaches to stone tool analysis. Newcastle: Cambridge Scholars Publishing. $223-252$.

Balikci, A. 1970. The Netsilik Eskimo. New York: Natural History Press.

Beattie, O., and Geiger, J. 1988. Frozen in time: Unlocking the secrets of the Franklin Expedition. Saskatoon, Saskatchewan: Western Producer Prairie Books.

Berton, P. 1988. The Arctic Grail. Toronto: McClelland and Stewart.

Best, S. 1977. The Maori adze: An explanation for change. Journal of the Polynesian Society 86(3):307-337. 
Biddle, R. 2009. Naval shipbuilding and the health of dockworkers c.1815 - 1871. Family \& Community History 12(2):107-116. https://doi.org/10.1179/146311809X12520565987214

Bradley, R. 2002. The past in prehistoric societies. London: Routledge.

Colligan, E.M. 2017. Thule iron use in the pre-contact Arctic. PhD dissertation, Department of Anthropology, City University of New York, New York.

Cunliffe, E.A. 2013. Whales and whale bone technology in New Zealand prehistory. MA thesis, University of Otago, Dunedin, New Zealand.

Cyriax, R.J. 1939. Sir John Franklin's last Arctic expedition: A chapter in the history of the Royal Navy. London: Methuen and Co. Ltd.

Damas, D. 1988. The contact-traditional horizon of the Central Arctic: Reassessment of a concept and reexamination of an era. Arctic Anthropology 25(2):101 - 138.

Ennos, A.R., and van Casteren, A. 2010. Transverse stresses and modes of failure in tree branches and other beams. Proceedings of the Royal Society B: Biological Sciences 277(1685):1253-1258.

Gilder, W.H. 1881. Schwatka's search: Sledging in the Arctic in quest of the Franklin records. New York: Charles Scribner's Sons.

Gowlett, J.A.J., and Wrangham, R.W. 2013. Earliest fire in Africa: Towards the convergence of archaeological evidence and the cooking hypothesis. Azania: Archaeological Research in Africa 48(1):5-30.

https://doi.org/10.1080/0067270X.2012.756754

Hickey, C.G. 1984. An examination of processes of cultural change among nineteenth century Copper Inuit. Études/Inuit/ Studies 8(1):13-35.

Hodder, I. 2012. Entangled: An archaeology of the relationships between humans and things. Oxford: Wiley-Blackwell.

Holland, A.J. 1971. Ships of British oak: The rise and decline of wooden shipbuilding in Hampshire. Newton Abbot: David \& Charles Publishers.

Hutchinson, G. 1984. A plank fragment from a boat-find from the River Usk at Newport. The International Journal of Nautical Archaeology 13(1):27-32.

https://doi.org/10.1111/j.1095-9270.1984.tb01174.x

Keenleyside, A., Bertulli, M., and Fricke, H.C. 1997. The final days of the Franklin expedition: New skeletal evidence. Arctic 50(1):36-46.

https://doi.org/10.14430/arctic1089

Klutschak, H. 1987. Overland to Starvation Cove: With the Inuit in search of Franklin, 1878-1880. Translated and edited by William Barr. Toronto: University of Toronto Press.

Kollman, F.P., and Côté, W.A., Jr. 1968. Principles of wood science and technology. Vol. 1: Solid wood. New York: SpringerVerlag.

Larsen, H.A. 1984. The North-West Passage 1940-1942 and 1944: The famous voyages of the Royal Canadian Mounted Police Schooner "St. Roch." Ottawa: The Royal Canadian Mounted Police Public Relations Branch.
Lavery, B. 1987. The arming and fitting of English ships of war 1600-1815. London: Conway Maritime Press.

Lyon, G.F. 1824. The private journal of Captain G.F. Lyon, of H.M.S. Hecla, during the recent voyage of discovery under Captain Parry. London: John Murray.

Martindale, A. 2009. Entanglement and tinkering: Structural history in the archaeology of the Northern Tsimshian. Journal of Social Archaeology 9(1):59-91. https://doi.org/10.1177/1469605308099371

Mays, S., Maat, G.J.R., and de Boer, H.H. 2015. Scurvy as a factor in the loss of the 1845 Franklin expedition to the Arctic: A reconsideration. International Journal of Osteoarchaeology 25(3):334-344.

https://doi.org/10.1002/oa.2305

McCarthy, M. 2005. Ships' fastenings: From sewn boat to steamship. College Station: Texas A\&M University Press.

McCartney, A.P., and Mack, D.J. 1973. Iron utilization by Thule Eskimos of Central Canada. American Antiquity 38(3):328-339.

https://doi.org/10.2307/279720

McClintock, F.L. 1860. The voyage of the 'Fox' in the Arctic seas. A narrative of the discovery of the fate of Sir John Franklin and his companions. Boston: Ticknor and Fields.

McGrail, S. 2004. To clench or to rivet: That is the question. The International Journal of Nautical Archaeology 33(1):149-153. https://doi.org/10.1111/j.1095-9270.2004.00012.x

McKee, E. 1983. Working boats of Britain: Their shape and purpose. London: Conway Maritime Press.

Morrison, D.A. 1987. Thule and historic copper use in the Copper Inuit area. American Antiquity 52(1):3 - 12. https://doi.org/10.2307/281056

Moss, A. 2006. Analysing iron knees to aid the identification of historic ship remains. Bulletin of the Australasian Institute for Maritime Archaeology 31:81-89.

Nourse, J.E., ed. 1879. Narrative of the second Arctic expedition made by Charles Francis Hall: His voyage to Repulse Bay, sledge journeys to the Straits of Fury and Hecla and to King William's Land, and residence among the Eskimos during the years 1864-'69. Washington, D.C.: U.S. Naval Observatory, Government Printing Office.

Parry, W.E. 1824. Journal of a second voyage for the discovery of a Northwest Passage from the Atlantic to the Pacific; performed in the years 1821-22-23, in His Majesty's ships Fury and Hecla. London: John Murray.

Pringle, H. 1997. New respect for metal's role in ancient Arctic cultures. Science 277(5327):766-767.

Rae, J. 1855. Sir John Franklin and his crews. Household Words 11(254):12-20.

Rasmussen, K. 1976 [1931]. The Netsilik Eskimos: Social life and spiritual culture. Report of the Fifth Thule Expedition 1921 -24, Vol. 8(1-2). New York: AMS Press.

Rios-Garaizar, J., Eixea, A., and Villaverde, V. 2015. Ramification of lithic production and the search of small tools in Iberian Peninsula Middle Paleolithic. Quaternary International 361:188-199.

https://doi.org/10.1016/j.quaint.2014.07.025 
Romagnoli, F. 2015. A second life: Recycling production waste during the Middle Palaeolithic in layer L at Grotta del Cavallo (Lecce, Southeast Italy). Quaternary International 361:200-211.

https://doi.org/10.1016/j.quaint.2014.07.033

Ross, J. 1835. Narrative of a second voyage in search of a Northwest passage, and of a residence in the Arctic during the years 1829, 1830, 1831, 1832, 1833. London: A.W. Webster.

Royal Museums Greenwich. 2018a. Gig (1838); Service vessel; Ship's boat.

http://collections.rmg.co.uk/collections/objects/66734.html

. 2018b. Pinnace (1838); Service vessel; Ship's boat. http://collections.rmg.co.uk/collections/objects/66736.html

Samuel, R. 1977. Workshop of the world: Steam power and hand technology in mid-Victorian Britain. History Workshop Journal 3(1):6-72.

https://doi.org/10.1093/hwj/3.1.6

Savelle, J.M. 1981. The nature of nineteenth century Inuit occupations of the High Arctic Islands of Canada. Études/ Inuit/Studies 5(2):109-123.

. 1985. Effects of nineteenth century European exploration on the development of the Netsilik Inuit culture. In: Sutherland, P., ed. The Franklin era in Canadian Arctic history 1845-1859. Mercury Series, Archaeological Survey of Canada Paper No. 131. Ottawa: National Museums of Canada. 192-214.

Schiffer, M.B. 1972. Archaeological context and systemic context. American Antiquity 37(2):156-165. https://doi.org/10.2307/278203

- 1987. Formation processes of the archaeological record. Albuquerque: University of New Mexico Press.

Schwatka, F. 1965. The long Arctic search: The narrative of Lieutenant Frederick Schwatka, U.S.A., 1878-1880, seeking the records of the lost Franklin expedition. Edited by E.A. Stackpole. Mystic, Connecticut: Marine Historical Association.

Seeb, S.K. 2013. Cape Fear's forgotten fleet: The Eagles Island ship graveyard, Wilmington, North Carolina. In: Richards, N., and Seeb, S.K., eds. The archaeology of watercraft abandonment. New York: Springer. 215-238.

Stahl, A.B. 2002. Colonial entanglements and the practices of taste: An alternative to logocentric approaches. American Anthropologist 104(3):827-845.

Stammers, M.K. 2001. Iron knees in wooden vessels-An attempt at a typology. The International Journal of Nautical Archaeology 30(1):115-121.

https://doi.org/10.1016/S1057-2414(01)80012-1

Stenton, D.R. 2014a. A most inhospitable coast: The report of Lieutenant William Hobson's 1859 search for the Franklin expedition on King William Island. Arctic 67(4):511 - 522. https://doi.org/10.14430/arctic4424

2 2014b. 2013 Franklin Search Expedition. Permit Report covering the work conducted under Nunavut Archaeologist Permit 2013-01A. Unpubl. report, Department of Culture and Heritage, Government of Nunavut, PO Box 1000, Station 200, Iqaluit, Nunavut X0A 0H0. 15 p.
Stenton, D.R., and Park, R.W. 2017. History, oral history and archaeology: Reinterpreting the "boat places" of Erebus Bay. Arctic 70(2):203-218. https://doi.org/10.14430/arctic4649

Stenton, D.R., Keenleyside, A., and Park, R.W. 2015. The "boat place" burial: New skeletal evidence from the 1845 Franklin expedition. Arctic 68(1):32-44. https://doi.org/10.14430/arctic4454

Stenton, D., Keenleyside, A., Fratpietro, S., and Park, R. 2017. DNA analysis of human skeletal remains from the 1845 Franklin expedition. Journal of Archaeological Science: Reports 16:409-419. https://doi.org/10.1016/j.jasrep.2017.03.041

Stockhammer, P.W. 2013. From hybridity to entanglement, from essentialism to practice. In: van Pelt, W.P., ed. Archaeology and cultural mixture. Archaeological Review from Cambridge 28(1):11-28.

Stone, G.L. 1981. The interpretation of negative evidence in archaeology. Atlatl (now Arizona Anthropologist) 2:41-53. https://journals.uair.arizona.edu/index.php/arizanthro/article/ view/18224/17959

Sutherland, P.D., ed. 1985. The Franklin era in Canadian Arctic history 1845-1859. Mercury Series, Archaeological Survey of Canada Paper No. 131. Ottawa: National Museums of Canada.

Swift, E. 2012. The analysis of reused material culture for Late Antique studies. Late Antique Archaeology 9(1):91-119. https://doi.org/10.1163/22134522-12340006

Thomas, N. 1991. Entangled objects: Exchange, material culture and colonialism in the Pacific. Cambridge, Massachusetts: Harvard University Press.

Turgeon, L. 2004. Beads, bodies and regimes of value: From France to North America, c. 1500-c. 1650. In: Murray, T., ed. The archaeology of contact in settler societies. Cambridge: Cambridge University Press. 19-47.

Walpole, G. 2017. Relics of the Franklin expedition: Discovering artifacts from the doomed Arctic voyage of 1845. Jefferson, North Carolina: McFarland \& Company, Inc.

Wayman, M.L. 1989. On the early use of iron in the Arctic. In: Wayman, M.L., ed. All that glitters: Readings in historical metallurgy. Montreal: The Metallurgical Society of the Canadian Institute of Mining and Metallurgy. 89-93.

Wilson, D.C. 1995. The analysis of domestic reuse in historical archaeology. In: Skibo, J.M., Walker, W.H., and Nielsen, A.E., eds. Expanding archaeology. Salt Lake City: University of Utah Press. 126-140.

Winfield, R. 2014. British warships in the Age of Sail 1817-1863: Design, construction, careers and fates. Yorkshire: Seaforth Publishing.

Woodman, D.C. 1991. Unravelling the Franklin mystery. Montreal: McGill-Queen's University Press.

Zori, D. 2007. Nails, rivets, and clench bolts: A case for typological clarity. Archaeologia Islandica 37:32-47. 